\title{
Between Madness and Self-redemption: A Foucaultian Study of Jessie's Committing Suicide in 'night, Mother
}

\author{
Chen Dang \\ Foreign Studies College, Hunan Normal University, China
}

\begin{abstract}
Having been nominated for the Tony Award for Best Play and won the 1983 Pulitzer Prize for Drama, 'night, Mother is well-received for its realism, honesty and a universal demonstration of man's living dilemma. Jessie's emptiness and loneliness is strengthened not only by her epilepsy but also by her life out of control. Behind her firmness in committing suicide, there are her alienation from the outside forces, desperation and hysteria under her calmness, and the discipline of as well as resistance towards existence. She confesses that her intention of killing herself is for "protection" and she chooses committing suicide as the tragic consequence of madness in both her mind and body, at the same time, she makes the first and last free choice for her self-redemption.
\end{abstract}

Index Terms_-'night, Mother, living dilemma, committing suicide, madness, self-redemption

\section{INTRODUCTION}

As Marsha Norman's fifth well-received play, 'night, Mother is written in 1981 and receives Pulitzer Prize for Drama when it is first staged in 1983. American theatrical critic Robert Brustein once compared this play with Long Day's Journey Into Night with regards to their similarities in family crisis of family members, except there is a clear demonstration of failed mother-daughter relationship in 'night, mother, which is characteristic of Norman's plays. The popularity of this play not only results from its feminist touch, but also lies in its inclusion of the suicidal theme. Therefore, it will definitely brings on some seminal impacts to its contemporary society.

Marsha Norman's depiction of alienation and helplessness does have bearing on her real life. Born in Louisville, Kentucky, she leads a disturbing childhood without expose to ideas that may challenge her family as pious fundamentalists, and what's worse, she has two failed marriages and two poor children. To some extent, her writing is the outlet for personal emotions and viewpoints of what the true life is like, especially from the family perspective. Therefore, her achievements in writing - American Theatre Critics Association award, Pulitzer Prize, a Tony Award nomination so on and so forth, all prove that fictional figures in her writings do find their empathy in the real world, especially for the Pulitzer Prize winner-'night, Mother, which delineates the human plight of existence typically in light of Jessie's suicidal option.

Revolving around Jessie's announcement of committing suicide, 'night, Mother evolves with her mother Thelma's continuing dissuasion to her from doing that and Jessie's well-prepared arrangements of petty trifles in daily life for her mother and her steps closer to the "final judgement", for a duration about one hour and a half between them. The more further the content of the dialogue goes, the more fearful and helpless her mother feels, and the stronger Jessie's determination to commit suicide is. Being unemployed and divorced, all Jessie has for life is hatred and desperation. So her mother's pretension of helplessness is actually a trick to help her daughter to find purpose in life. However, with a husband who cheats on her and a son who has an inclination to steal things and addiction to drugs, Jessie, as an epileptic in her thirties, likens her life to the journey of a bus trip because every stop is the same, just as her life where there is no future and hope. Thelma feels jealous for Jessie's close relationship with her father even in his deathbed, and her love is not convincing and reasonable enough for Jessie's continuous life. In the end, she ends up with calling her son with a grief-stricken heart when she hears the sound of a gunshot.

When it is premiered at the American Repertory Theater, this play receives overwhelmingly favorable reviews regardless of some dissensions as to its trivial daily items such as food, "kitchen", chores and so on. However, feminists are controversial about it because some claim that the play is a demonstration of internal free choice when man loses control of life while others pose the behavior of committing suicide is in nature a symptom of capitulation. Although criticisms are divided, they do provide certain possibilities and proofs for the interpretation of this play. With the third wave of feminist movement in the 1980s and 1990s when women claims not the sexual politics but the textual politics, studies at home and abroad both have something to do the role of women. However, they are not completely the same with each other. Apart from the feminist criticisms, studies at abroad also focus on geopolitics, mirror images of violence and gender, general overview of theatrical realism and domestic issues, especially the mother-daughter relationships in terms of their specific and unique circumstances of society. In the meantime, studies at home seems a 
little retarded, limited and abstract, with their attention on the psychological, stylistic, linguistic, existential side and so on. In contrast, reviews at home has less concern with the action itself-committing suicide and the significance behind it. Therefore, based on this central action of the play, this paper attempts to exert a Foucaultian study to further explore what is behind Jessie's choice of committing suicide between her madness and self-redemption-the control of life in her own hands.

\section{BEHIND JESSIE'S MADNESS}

Being a woman in her late thirties or early forties, Jessie, as an epileptic, feels nothing but incapability to deal with her life, no matter with her failure in a broken marriage, or her delinquent son. Her epilepsy to some extent deprives her of the possibility to live a normal life and she regards her life as purposeless, empty and even hopeless. When she suffers from seizures, she loses control of her own normal behaviors and life, but even if she goes back to normality and reality, she is faced up with everything existential beyond alteration - the loss of her beloved dog, a failed marriage, her astray son and even the death of her father who has intimacy with her when he is alive. She is actually a woman who psychologically and physically lives on the edge of madness when she resorts to commit suicide for the final autonomy. As what Foucault poses in his book Madness and Civilization, "what is in question is still the nothingness of existence, but this nothingness is no longer considered an external, final term, both threat and conclusion; it is experienced from within as the continuous and constant form" (Foucault, 1988, p. 16). Jessie's final choice indicates that "madness is not linked to the world and its subterranean forms, but rather to man, to his weaknesses, dreams, and illusions" (Foucault, 1988 , p. 26), and her choice is in some way an demonstration of her illusions for the afterlife when she is on the brink of death.

\section{A. Alienation from Outside Forces}

The ninety-minute play presents a panoramic picture of a mother-daughter relationship. At the beginning, Jessie' mother has troubled her daughter with many trifles which she thinks can endow meanings and purposes with her daughter's life_ “Jessie, it's the last snowball, sugar. Put it on the list, O.K.? And we're out of Hershey bars, and where's that peanut brittle... What have you been doing in there" (Norman, 2004, p. 743)? It seems that she is incapable of dealing with everything even her own life, and all she does is try to keep her daughter at her service and keep track of the whereabouts about her daughter wherever she goes. Later, when the dialogue between mother and daughter develops, we learn that she is a widow with two children, but one son lives with his wife. Besides, she lives a rather lonely and pathetic life because there is little communication and love in her marriage. "Did you love Daddy? No...It was a big fat lie, the whole thing...He felt sorry for me...He never said a word he didn't have to, Jessie....How could I love him, Jess. I didn't have a thing he want-ed" (Norman, 2004, p. 764). Therefore, Jessie, who is taken in by her when she separates with her husband Cecil, is the only one that she can have control over in her life. Her manipulation or deformed love turns out to be an impediment and prison for her daughter's seeking for identity. She not only conceals the fact that Jessie suffers from epilepsy and also arranges her marriage - "he's the best carpenter I ever saw. That little house of yours will still be standing at the end of the world, Jessie...All right! I wanted you to have a husband" (Norman, 2004, p. 771). Jessie, not like her brother who can choose to live with his wife Loretta, does not have any dominance over daily trifles or even her marriage. Her son, though behaves delinquently, can have control over his own life.

Jessie's alienation and loneliness is a clear demonstration of her reaction to the outside forces. As a result of her epilepsy, she feels complete isolation and even fails the attempt to have a whole family. For her protection, her mother Thelma hides the fact that she is an epileptic but this on the other hand, also separates her from the outside world. Her loneliness leads to her mother's decision to hire a construction worker on the porch building. What's worse, she loses her ability to have a normal work because of her epilepsy, but when her disease is under control, she loses her courage to take a step further to the outside world. Because "there wasn't anything you could say to change my mind. I didn't want you to save me. I just wanted you to know" (Norman, 2004, p. 780), her determination and passion to commit suicide - "I won's be here. If I'd ever had a year like this, to think straight and all, before now, I'd be gone already" (Norman, 2004, p. 777), in Foucault's words, is a "more constant, more persistent, and somehow more deserved cause of madness" ( Foucault, Madness, 1988, p. 85) and this kind of strong emotion can been treated as an "interior phenomenon that arises from one's material nature spontaneously or as a consequence of the material connection to externality; all these potentially disturb stability of mind" (Strozier, 2002, p. 180). There is no doubt the fact that Jessie's determination to kill herself originates from the alienation and loneliness of her own life.

\section{B. Desperation and Hysteria Under Jessie's Calm}

After the announcement of her tendency to commit suicide, Jessie presents herself as being very calm to be confronted with her mother's plea, fear, anger, desperation and disbelief_- "Don't leave me, Jessie! No...How can I live here without you? I need you!" (Norman, 2004, p. 779). Apart from that, she copes with everything she may leave behind in detail and with patience- " I have a box of things I want people to have" (Norman, 2004, p. 779). Not like what her mother has assumed that "if you've got the guts to kill yourself, Jessie, you've got the guts to stay alive" (Norman, 2004, p. 780), Jessie suffers a lot more than anyone around her can imagine.

Under her pretentious tranquility, there is truly her desperation and hysteria- "I'm tired. I'm sad. I feel used" 
(Norman, 2004, p. 755). This is actually her cry and inner voice against everything that has collapsed in her life. She is a lost woman who cannot find the direction in her world and all she can do is to resort to a dead end where there is no bother to face up with the reality. So even when Christmas which symbolizes rebirth is around the corner, she comes up with the idea of killing herself because she sees life as the way out and deliverance from suffering and pain. Life to her, is no longer the epitome of hope and future, because "I can't do anything either, about my life, to change it, make it better, make me feel better about it. Like it better, make it work. But I can stop it. Shut it down, turn it off like the radio when there is nothing I want to listen to" (Norman, 2004, p. 759). All her words are uttered in a very short form in that she is really going through desperation and hysteria in her own mind. The more Jessie feels desperation of life, the more she desires to have the final say to her life, leaving her hysteria in mind to the verge of committing suicide. Just as what Foucault holds for hysteria, "incoercible agitation of desires" ( Foucault, Madness, 1988, p. 150) which "they had neither the possibility of satisfying them nor the strength to master them" (Foucault, Madness, 1988, p. 150).

In her book Madness in Literature, Lillian Feder claims that: "In attempting to cover persistent and variable characteristics of actual as well as literary madness, I define madness as a state in which unconscious processes predominate over conscious ones to the extent that they control them and determine perceptions of and responses to experiences that, judged by prevailing standards of logical thought and relevant, emotion, are confused and inappropriate" (Feder, 1980, p. 5).

As a matter of fact, behind Jessie's ostensible tranquility, there lies her intense and uncontrollable madness both physically and psychologically which results from her alienation from outside forces, desperation and hysteria for life and her final choice to end her life irrationally.

\section{DisCIPLINE AND RESISTANCE OF JESSIE}

Just at the beginning of the play, the announcement of Jessie's intention of committing suicide is in some way an indication of her resistance. Being in the phase of her middle age, she feels that she is trapped and impotent in life for the abandonment of her husband, a son who steals things and is drug-addicted, and her inability to hold a job because of her epileptic fits. Just as an emblem of the dilemma as a woman in society, she considers epilepsy as the last straw for making her out of control and unconscious, only to be dominated by others. Therefore, in her mind, she thinks that if she has no right over her birth, then she can handle the right of death by her own. Just as what Foucault describes the power function of controlling one's own behaviors, minds and daily life. Her proclamation of killing herself is the resistance of her inner heart and responses to disciplinary forces.

\section{A. Struggle and Discipline of Jessie}

Jessie's dialogue with her mother before the completion of her intention does reveal her inward struggle. Regardless of Thelma's cajoling, pleading and exhortation, she remains implacable with continuous self-reflecting and self-assessing: "Riding the bus and it's hot and bumpy and crowded and too noisy and more than anything in the world you want to get off and the only reason in the world you don't get off is it's still fifty blocks from where you are going? Well, I can get off right now if I want to, because even if I ride fifty more years and get off then, it's the same place when I step down to it. Whenever I fell like it, I can get off. As soon as I've had enough, it's my stop. I've had enough" (Norman, 2004, p. 757).

Therefore, for Jessie, life is hopeless and empty and when Christmas comes, she has a clearer awareness of how nihilistic her life is. That ninety-minute talk between mother and daughter reveals much about her living conditions- "I've never been around people my whole life except when I went to the hospital. I could have a seizure anytime. What good would a job do? The kind of I could get would make feel worse (Norman, 2004, p. 758).

Jessie is actually a trapper in life and she is disciplined by both of the outside forces and her own physical conditions. Her knowledge of and discourse with the whole world is limited by disciplinary and penal power. Madness in Foucault's words, results from civilization which leads to his outstanding power theory and he emphasizes that knowledge is paramount in disciplining prisoners because "power produces knowledge (and not simply by encouraging it because it serves power or by applying it because it is useful); that power and knowledge directly imply one another; that there is no power relation without the correlative constitution of a field of knowledge, nor any knowledge that does not presuppose and constitute at the same time power relations" (Foucault, Discipline, 1995, p. 27-8)

Jessie's recognition of herself is largely based on her outside forces and and the latter at the same time disciplines and puts her into great suffering and struggle. Her choice of committing suicide is to some extent a punishment from society and even if outside forces 'do not make use of violent or bloody punishment, even when they use 'lenient' methods involving confinement or correction, it is always the body that is at issue - the body and it's forces, their utility and their docility, their distribution and their submission" (Foucault, Discipline, 1995, p. 25).

\section{B. Demonstration of Jessie's Silent Resistance}

Before she shoots herself, Jessie arranges the whole evening to stay with her mother and makes a list of things she thinks that may be convenient to her families. The reason why she rummages for her father's gun is for "protection" (Norman, 2004, p. 745). She does not responds to her mother correspondingly and just does what she has in mind and wants to have everything well-prepared before she's gone. She collects old towels and pillows to minimize the chaos 
when she kills herself and such meticulousness presents her desire for control and dominance regardless of her numbness and negligence towards her surroundings. Besides, she even tells her mother that she should "be more selfish from now on. Now somebody's bound to ask you why I did it and you just say you don't know. That you loved me and you know I loved you and we just sat around tonight like every other night of our lives, and then I came over and kissed you and said, "Night, Mother, and you heard me close my bedroom door and the next thing you heard was the shot. And whatever reasons I had, well, you guess I just took them with me" (Norman, 2004, p. 785)

Jessie is actually resisting all the time when she announces her intention and her resistance is in silence. She wants to keep the root of her committing suicide a secret and distances it from anyone that may be associated with it, and she draws back to her own being as an individual with dignity. That is the demonstration of her silent resistance and her true ego. Just as what Foucault asserts in his book The History of Sexuality, "discourse can be both an instrument and effect of power, but also a hindrance, a stumbling-block, a point of resistance and a starting point for an opposing strategy. Discourse transmits and produces power; it reinforces it, but also undermines and exposes it, renders sexuality fragile and makes it possible to thwart it" (Foucault, Sexuality, 1990, p. 101).

This statement indicates the paradox of discourse to power and the counterforce of resistance. Though Jessie is mainly tortured and punished by the disciplinary power, she still holds her own control of the right of life and death and isn't totally suppressed. She resists in her own implacable way- "she vanishes into her bedroom and we hear the door lock just as Mama gets to it”' ( Norman, 2004, p. 788).

\section{To Be Or Not To BE}

Although Jessie kills herself as a way to resist and an announcement for her autonomy, the fact that she commits suicide can never be treated as a tragedy too much. Suicide as a consequence of madness is a real projection of man's living plight - to be or not to be, and the gap between hope and reality. This kind of tragedy in Aristotle's words, is "enriched by a variety of artistic devices appropriate to the several parts of the play; presented in the form of action, not narration; by means of pity and fear brings about the purgation of such emotions" (Aristotle, 2007, p. 22). Jessie, being described in the image of a self-destructive woman for the expression of desires for self control and freedom, deserves careful deliberation.

\section{A. Confession: for "Protection"}

Foucault holds in his lectures at Dartmouth college that "for a long time either as a condition or redemption for one's sin or an essential item in the condemnation of the guilty. For his salvation, one has to know 'as exactly as possible who he is' and, adding to this, one is required to express it as fully and explicitly as possible to other people" (Foucault, Lectures, 2016, p. 20).

When Thelma asks her daughter why she attempts to find her father' gun, she replies with "protection" (Norman, 2004, p. 745) by “ I' going to killing myself” (Norman, 2004, p. 747) because " I'm just not having a very good time and I don't have any reason to think it'll get anything but worse. I'm tired. I'm hurt. I'm sad. I feel use...It all" (Norman, 2004, p. 755). She kills herself for the protection of her life, her dignity and her ego. Being a woman in her middle age, with a failed marriage, delinquent son, alienation from the outside world and a purposeless life, Jessie is pathetic and lost. Because of the concealment of her epilepsy, people around her feels fearful and strange towards her because "her hands are cold...Like a corpse...Jessie' shook the hand of death and I can't take the chance it's catching, Thelma, so I' ain't comin' over, and you can understand or not, but I ain't coming'. I'll come up the driveway, but that's as far as I go"' (Norman, 2004, p. 763). She is helpless when her epilepsy deprives her of the possibility to work normally and feels lonely and painful because even if the ambulance comes for her seizures, "all they ever did for me in the emergency room was let me wake" (Norman, 2004, p. 770). Therefore, to Jessie, if no one can help and come to her assistance, she can potect herself, by way of leaving the world which has greatly put her into struggle and loss.

Jessie's statement of "protection" is her last autonomy in extremity and a prelude for her tragic end. Her suicidal behavior is a true demonstration of her last confession and the "representation of an action that is worth serious attention, complete in itself, and of some amplitude" (Aristotle, 2007, p. 22).

\section{B. Self Redemption: Suicide as a Consequence of Madness}

As a middle-aged woman who seems to be deserted by the whole world, Jessie seeks shelter in death which is a significant section of the life-death cycle. On the one hand, death may be treated as determinism which leads to people's fear of death, however, on the other hand, death provides the possibility of poeple's self-accomplishment and freedom from restraints. And that's why Jessie is firm in her choice to commit suicide - to free herself from constraints. She is suffering a lot both physically and psychologically, and from her reason to the behavioral madness of her intention to commit suicide is a kind of confinement, which in Foucault's words, "this particular form of sensibility traces the features proper to madness in the world of unreason. It is particularly concerned with scandal. In its most general form, confinement is explained, or at least justified, by the desire to avoid scandal" (Foucault, Madness, 1988, p. 66) and Jessie's determination to kill herself, "in the general sensibility to unreason, there appeared to be special modulation which concerned madness proper, and was addressed to those called, without exact semantic distinction, insane, alienated, deranged, demented, extravagant" (Foucault, Madness, 1988, p. 66). Jessie chooses to have a dialogue with 
only her mother and keeps everyone out of it to avoid any scandal and meddlesome persons to get involved, and even her death scene only concerns with herself and a gun, embracing that her death should be a mystery and no one should know why except herself. Her committing suicide is actually a demonstration of animal instinct to protect themselves from dangers as a consequence of madness because "madness, insofar as it partook of animal ferocity, preserved man from the dangers of disease; it afforded him an invulnerability, similar to that which nature, in its foresight, had provided for animals" (Foucault, Madness, 1988, p. 75).

As for Foucault, "madness shows us nothing more than the natural contants of a determinism, with the sequences of its causes, and the discursive movement of its forms; for madness threatens modern man only with that return to the bleak world of beasts and things, to their fettered freedom" (Foucault, Madness, 1988, p. 83) and "all these phenomenon, these strange practices woven around madness, these usages which glorify and at the same time discipline it, reduce it to animality while making it reach the lesson of the Redemption, put madness in a strange position with regard to unreason as a whole" (Foucault, Madness, 1988, p. 82).

On the one hand, Jessie's announcement of killing herself is in essence a symbol for her deranged psyche; on the other hand, her final choice is a conduct of self-redemption, and she, "the madman, tracing the course of of human degradation to the frenzied nadir of animality, disclosed that underlying realm of unreason which threatens man and envelops - at a tremendous distance — all the forms of his natural existence" (Foucault, Madness, 1988, p. 83). Jessie's living dilemma and derangement in life is typical for each human being's existence.

\section{CONCLUSION}

When Jessie decides to kill herself, she suffers torture on her own psyche and she is on the brink of madness. She attempts to conduct the final autonomy to recreate her soul and reason, and reflect on her own consciousness. "Protection" is her recognition and confession of the meaning of her committing suicide and she regards it as the only way to find hope and meaning in life regardless of her psychological derangement and nihilism. She suffers pain and desperation and it seems that she is an invisible woman whom everyone does not give a little care about. She can not find her sense of belonging and chooses suicide as a consequence of madness and a way of self-redemption. Between her madness and self-redemption, there lies the discipline of outside forces and her resistance towards it.

In some sense, Jessie's committing suicide is a way of resistance but also, it is a pessimistic and selfish behavior which rids her of the reality. This kind of determinism and selfishness is in turn strengthening her loneliness and alienation from the outside world. Human existence is essentially a trap of life-death cycle, in which human beings have no right to decide their right of birth, but the attitude towards death is what really matters.

\section{REFERENCES}

[1] Aristotle. (2007). On the Art of Poetry. Beijing: Jiu Zhou Press.

[2] Feder, Lillian. (1980). Madness and Literature. Princeton: Princeton University Press.

[3] Foucault, Michel. (2016). About the Beginning of the Hermeneutics of the Self: Lectures at Dartmouth College. Eds. Henri-Paul Fruchaud and Daniele Lorenzini. Tans. Graham Burchell. Chicago: Chicago UP.

[4] Foucault, Michel. (1995). Discipline and Punish: The Birth of the Prison. Trans. Alan Sheridan. New York: Vintage Books.

[5] Foucault, Michel. (1988). Madness and Civilization: A History of Insanity in the Age of Reason. Trans. Richard Howard. New York: Vintage Books.

[6] Foucault, Michel. (1990). The Will to Knowledge, The History of Sexuality. London: Penguin.

[7] Norman, Marsha. (2004). "'night, Mother." British and American Drama: Plays and Criticism. Eds. Liu Haiping and Zhu Xuefeng. Shanghai: Shanghai Foreign Language Education Press, p. 739-89.

[8] Smith, Raynette Halvorsen. (1991). “"night, Mother' and True West: mirror images of violence and gender.” Themes in Drama, Vol. 13, p. 277-89.

[9] Strozier, Robert. (2002). Foucault, Subjectivity, and Identity: Historical Constructions of Subject and Self. Detroit: Wayne State University Press.

Chen Dang was born in Henan, China in 1995. She is now studying in Changsha, China at Hunan Normal University as a postgraduate student. Her major is British and American Literature 